\title{
Medicinal Plants Used in Ethnoveterinary Practices in Adea Berga District, Oromia Region of Ethiopia
}

\author{
Megersa Feyisa, ${ }^{1}$ Addis Kassahun, ${ }^{1}$ and Mirutse Giday $\mathbb{D}^{2}$ \\ ${ }^{1}$ Faculty of Veterinary Medicine, Hawassa University, P.O. Box 05, Hawassa, Ethiopia \\ ${ }^{2}$ Aklilu Lemma Institute of Pathobiology, Addis Ababa University, P.O. Box 1176, Addis Ababa, Ethiopia
}

Correspondence should be addressed to Mirutse Giday; mirutse.giday@aau.edu.et

Received 19 July 2021; Accepted 18 December 2021; Published 30 December 2021

Academic Editor: Mohammed S. Ali Shtayeh

Copyright $(02021$ Megersa Feyisa et al. This is an open access article distributed under the Creative Commons Attribution License, which permits unrestricted use, distribution, and reproduction in any medium, provided the original work is properly cited.

In Ethiopia, locally available materials, mainly medicinal plants, are commonly utilized to manage livestock diseases. However, this practice is currently being threatened by several factors including loss of traditional knowledge and depletion of plant resources. This calls for an urgent need to document the ethnoveterinary knowledge in the country and conserve the associated medicinal plants. The purpose of this study was, therefore, to document traditional knowledge on use of medicinal plants in the Adea Berga district, Oromia region of Ethiopia, to manage livestock ailments. Ethnobotanical data were collected largely through semistructured interviews conducted with purposively selected traditional healers of the district. The study identified 59 medicinal plants used in ethnoveterinary practices in the district. The great majority (90.4\%) of the medicinal plants were used in fresh forms, which were mainly administered orally. The majority $(65.4 \%)$ of the medicinal plants were gathered from the wild. Data revealed that yoke sore (wound) had the highest informant consensus factor (ICF) value (1.00), followed by leech infestation (0.92) and endoparasite infections (0.90). The highest fidelity level (FL) (100\%) and rank order priority (ROP) (100\%) values were obtained for the plants Nicotiana tabacum, Malva parviflora, and Calpurnia aurea that were used to treat leech infestation, retained placenta, and snake poisoning, respectively. Priority for further pharmacological and phytochemical investigations needs to be given to the aforementioned three plants with the highest FL and ROP values as such values may indicate their higher potency against the respective ailments.

\section{Introduction}

Ethiopia is one of the leading countries in the world and the first in Africa in terms of livestock population. However, livestock productivity is far below the possible expectations and, as a result, the country could not fulfill its local demands and hence imports animal products from other countries. One of the major challenges of livestock production in the country is the high prevalence of different diseases affecting domestic animals [1]. As most modern drugs are expensive and not affordable for the majority of Ethiopian farmers and pastoralists, disease control measures largely depend on traditional medicine, which mainly involves the use of medicinal plants [2]. According to estimate of Abebe and Ayehu [3], 95\% of traditional medical preparations in Ethiopia are of plant origin.
However, despite the huge contribution of medicinal plants in the Ethiopian animal healthcare system and rich traditional medical knowledge, little effort has so far been made to properly document ethnoveterinary-related knowledge and conserve the associated medicinal plants in an effort to ensure their better and sustainable uses. As a result, the majority of the knowledge has been left undocumented being exposed to serious depletion due to acculturation and expansion of modern education. It is worth noting that in the Ethiopian traditional medical system, knowledge is handed down from generation to generation largely by word of mouth with little culture of documentation and as a result there is high probability that a portion of it could be lost in the process. The continuation of the practice is also negatively affected by the depletion of medicinal plants used in the system mainly due to agricultural 
expansion and deforestation. Therefore, there is an urgent need for conducting more ethnoveterinary surveys in different parts of the country to save the traditional knowledge and the associated medicinal plants from further loss.

Some ethnobotanical surveys have so far been conducted in the Oromia region of Ethiopia, including that in Borana [2], Bale Mountains National Park [4], Chiro district [5], the Dabo Hana district of Illubabor zone [6], four districts of Jimma zone [7], selected districts of East Wollega zone [8], Horro Gudurru district [9], Yabelo and Liben districts [10], the Melkabello district of East Hararghe zone [11], the Midakegn district of West Shewa zone [12], Eastern Shewa and Arsi zones [13], Kelem Wollega zone [14], the Dale Sadi district of West Hararghe zone [15], the Berbere district of Bale zone [16], Wolmera district [17], and Ambo district [18], with the purpose of documenting knowledge exclusively focused on medicinal plants used to control livestock ailments. However, to the knowledge of the authors, there is no study conducted in the Adea Berga district to document medicinal plants traditionally used to manage livestock ailments. The purpose of this study was, therefore, to document traditional knowledge on the use of medicinal plants by people in the Adea Berga district, West Shewa zone, the Oromia region of Ethiopia, to manage livestock ailments.

\section{Materials and Methods}

2.1. Description of Study District. Ethnoveterinary study to document medicinal plants used to manage livestock diseases was conducted in the Adea Berga district, West Shewa zone, the Oromia regional state of Ethiopia. The Adea Berga district is located between $9^{\circ} 12^{\prime}$ and $9^{\circ} 37^{\prime} \mathrm{N}$ latitude and $38^{\circ}$ $17^{\prime}$ and $38^{\circ} 36^{\prime}$ E longitude [19] at $70 \mathrm{~km}$ west of Addis Ababa and $35 \mathrm{~km}$ northwest of the Holeta town. The district shares borders with the Walmera district in the south, Ejerie district in the southwest, Meta Robi district in the west, and the Muger River in the north and east. Enchni is the administrative town of Adea Berga district. The district has altitudes that range between 1371 and 3169 meters above sea level [20]. In the district, rainfall ranges between 800 and $1400 \mathrm{~mm}$ and temperature between $10^{\circ} \mathrm{C}$ and $29^{\circ} \mathrm{C}$ [19]. The district is divided into 34 administrative subdistricts (kebeles), the smallest administrate unit in Ethiopia.

Human population of the district is estimated to be 184,618, of which 92,277 are males and 92,341 are females (Adea Berga District Health Bureau, unpublished report, 2021). Mixed crop and livestock farming systems are the mode of agriculture in the study area. According to unpublished data from Adea Berga District Livestock and Fisheries Resources Office obtained in 2018, the district is estimated to have 165,317 heads of cattle, 56,800 sheep, 30,092 goats, 72,965 poultry, 14,208 donkeys, and 519 mules. Fascioliasis, pasteurellosis, foot-and-mouth disease (FMD), tick infestation, lice infestation, black leg, African horse sickness, lumpy skin diseases, sheep pox, Newcastle diseases, fowl cholera, and fowl pox are the commonly occurring diseases in the district (Adea Berga District Rural and Agricultural Development Office, unpublished report, 2011).
2.2. Selection of Study Sites and Informants. A reconnaissance survey was conducted in the Adea Berga district in November 2018 with the purpose of identifying study sites and identification of informants. Accordingly, nine subdistricts distributed in three agroecological zones of the district were identified for the study with the recommendation of elders and local authorities. These were Bishaan Diimoo, Kaaloo, Haroo Lemman, Oddoo Modjo, Iluu Kitabaa, Caancoo Birrattee, Adadaa Soddolbee, Iluu Coqorsaa, and Odaa Dalotaa. The elders and local authorities also assisted in the purposive sampling of 63 traditional healers from the nine subdistricts of the Adea Berga district to be involved in interviews.

2.3. Data Collection. Ethnoveterinary survey was conducted between November 2018 and March 2019, and data were mainly collected through semistructured interviews conducted with the selected traditional healers following the method of Martin [21]. The interview was based on a checklist of questions prepared in English and later translated to Afaan Oromoo, the local language in the study district. During interviews, data mainly regarding demographic characteristics of respondents, local name of medicinal plants employed in the practice, plant part used, remedy preparation methods, route of administration, disease treated, dosage regimen, remedy storing options, and habitat of medicinal plants used were gathered.

\subsection{Collection, Preparation, and Identification of Plant} Specimens. After every interview, walks were made with each informant to gather specimens of the claimed medicinal plants. The collected specimens were properly pressed and dried and later identified by their scientific name with the help of botanists at the Aklilu Lemma Institute of Pathobiology (ALIPB), Addis Abba University (AAU), and the National Herbarium (AAU), and vouchers were deposited in a mini-herbarium at ALIPB.

2.5. Data Analysis. Ethnoveterinary data were tabulated in Microsoft Excel spreadsheets and analyzed using SPSS version 20 software. The most useful information gathered on medicinal plants was summarized using descriptive statistical methods such as frequencies and percentages. The fidelity level (FL) value was computed for every medicinal plant reported by three or more informants, which is a measure of the degree of agreement among informants in the selection of a given medicinal plant to treat a given ailment, an indication of the possible level of efficacy. The fidelity level value was calculated using the formula $\mathrm{FL}=$ $I p / I u \times 100$, where $I p$ is the number of informants who reported the utilization of medicinal plants against a specific ailment and $I u$ is the total number of informants who mentioned the same plant against any ailment [22]. However, plants with similar FL values but known to different numbers of informants may vary in their healing potential. Thus, a correlation index known as relative popularity level (RPL) is additionally needed to be computed, and the rank 
order priority (ROP) value is determined by multiplying FL value by RPL value to differentiate the healing potential of plants of similar FL values [22, 23]. The RPL values range between 0 and 1 . The plants are categorized into "popular" $(\mathrm{RPL}=1)$ and "unpopular" ( $\mathrm{RPL}<1)$ groups. In this study, popular plants were those cited by more than half of the highest number of informants who cited a plant against an ailment, which is 27 . Accordingly, medicinal plants cited by 14 or more informants were considered popular and were assigned with an RPL value of 1 , whereas medicinal plants that were mentioned by less than 14 informants were considered unpopular and were assigned with RPL values less than 1 and were determined by dividing the total number of informants who mentioned the plant against a given ailment by 14 .

Informant consensus factor (ICF) values were computed to determine the level of agreement of informants in the district on use of medicinal plants to treat a given ailment category. Informant consensus factor values may help in the selection of medicinal plants for phytochemical and pharmacological studies [24]. Informant consensus factor values were calculated using the formula $\mathrm{ICF}=(n u r-n t) /(n u r-1)$, where nur is the number of usereports for a particular use category and $n t$ is the number of taxa used for a particular use category by all informants [25].

\section{Results}

3.1. Demographic Characteristics of Informants. Out of the total 63 informants who were identified for the interviews, 51 $(80.95 \%)$ were males and $12(19.05 \%)$ were females. The majority (53.73\%) of the informants were illiterate (Table 1).

3.2. Medicinal Plants Reported and Ailments Treated. The study recorded a total of 59 medicinal plants (distributed in 35 families) used in the Adea Berga district to treat 35 livestock ailments, of which 55 were identified to a species level, three to a genus level, and only one to a family level (Table 2). The family Asteraceae had the highest number of medicinal plants accounting for six $(10.17 \%)$ of the total medicinal plants, followed by Euphorbiaceae, Lamiaceae, and Solanaceae, each contributing four (6.78\%) medicinal plants. The families Cucurbitaceae, Fabaceae, and Poaceae contributed three $(5.09 \%)$ species each, whereas families Brassicaceae, Myrsinaceae, Rosaceae, and Rutaceae contained two (3.39\%) medicinal plants each. Each of the rest 24 families was represented by single species. Of the total medicinal plants, 31(52.54\%) were herbs, 18 (30.51\%) were shrubs, and $10(16.95 \%)$ were trees.

3.3. Medicinal Plant Parts Used and Methods of Preparation. Most remedies in the district were prepared from leaves accounting for $54.24 \%$ of the total medicinal plants reported, followed by plants that were harvested for their root $(11.86 \%)$ and seeds (10.17\%) (Figure 1). The most employed method of remedy preparation was crushing and squeezing or squeezing, accounting for $36(61.02 \%)$ of the total preparations, followed by chewing, which accounted for 7
TABle 1: Demographic characteristics of informants in the Adea Berga district.

\begin{tabular}{lcc}
\hline Parameters & Frequency & Percent (\%) \\
\hline Age, years & & \\
25-40 & 20 & 31.75 \\
40-45 & 32 & 50.79 \\
$\quad$ Above 55 & 11 & 17.46 \\
Sex & & \\
$\quad$ Females & 12 & 19.04 \\
$\quad$ Males & 51 & 80.95 \\
Education level & & \\
$\quad$ Illiterate & 34 & 53.97 \\
$\quad$ Elementary school & 10 & 15.87 \\
$\quad$ Secondary school & 16 & 25.40 \\
$\quad$ University degree holder & 3 & 4.76 \\
\hline
\end{tabular}

(11.86\%) of the preparations. Seven (11.86\%) medicinal plants are used in unprocessed form. Other methods of remedy preparation methods included grinding, chopping, roasting, and smoking.

3.4. Conditions of Medicinal Plants and Diluents Used in Remedy Preparations. Most of the medicinal plants used in remedy preparations were in their fresh form, accounting for $48(81.36 \%)$ of the total claimed medicinal plants. Six $(10.17 \%)$ medicinal plants were used either in dry or fresh form, and 5 (8.47\%) were used in dry form. The commonly used diluent in the preparation of medicinal plant remedies was water accounting for $54.24 \%$ of the total preparations, followed by saliva (11\%). Some $(33.9 \%)$ of the medicinal plant did not need diluents in their preparations.

3.5. Routes of Remedy Administration. Nearly half (45.76) of the medicinal plants were administered through oral route, followed by those were administered topically (25.42) and nasally (10.17) (Table 3 ).

3.6. Informant Consensus Factor. Informant consensus factor (ICF) values for the different ailment categories were calculated, and the results show the highest score for yoke sore (wound) (1.00), followed by leech infestation (0.92), endoparasites infections (0.90), ectoparasites infections (0.88), retained placenta (0.88), snake poisoning (0.88), and evil eye (0.88) (Table 4). Medicinal plants used to treat ailment categories of high ICF values include Aloe pubescens for treating yoke sore; Buddleja polystachya, Capsicum annuum, Millettia ferruginea, and Nicotiana tabacum for treating leech infestation; and Cucumis ficifolius, Embelia schimperi, Hagenia abyssinica, and Lepidium sativum for treating endoparasites infections.

3.7. Fidelity Level and Rank Order Priority Values. Medicinal plants that scored the highest fidelity level (FL) (100\%) and rank order priority (ROP) (100\%) values include Malva parviflora, Nicotiana tabacum, and Calpurnia aurea that were used to expel retained placenta, remove leeches, and treat snake poisoning, respectively (Table 5). 


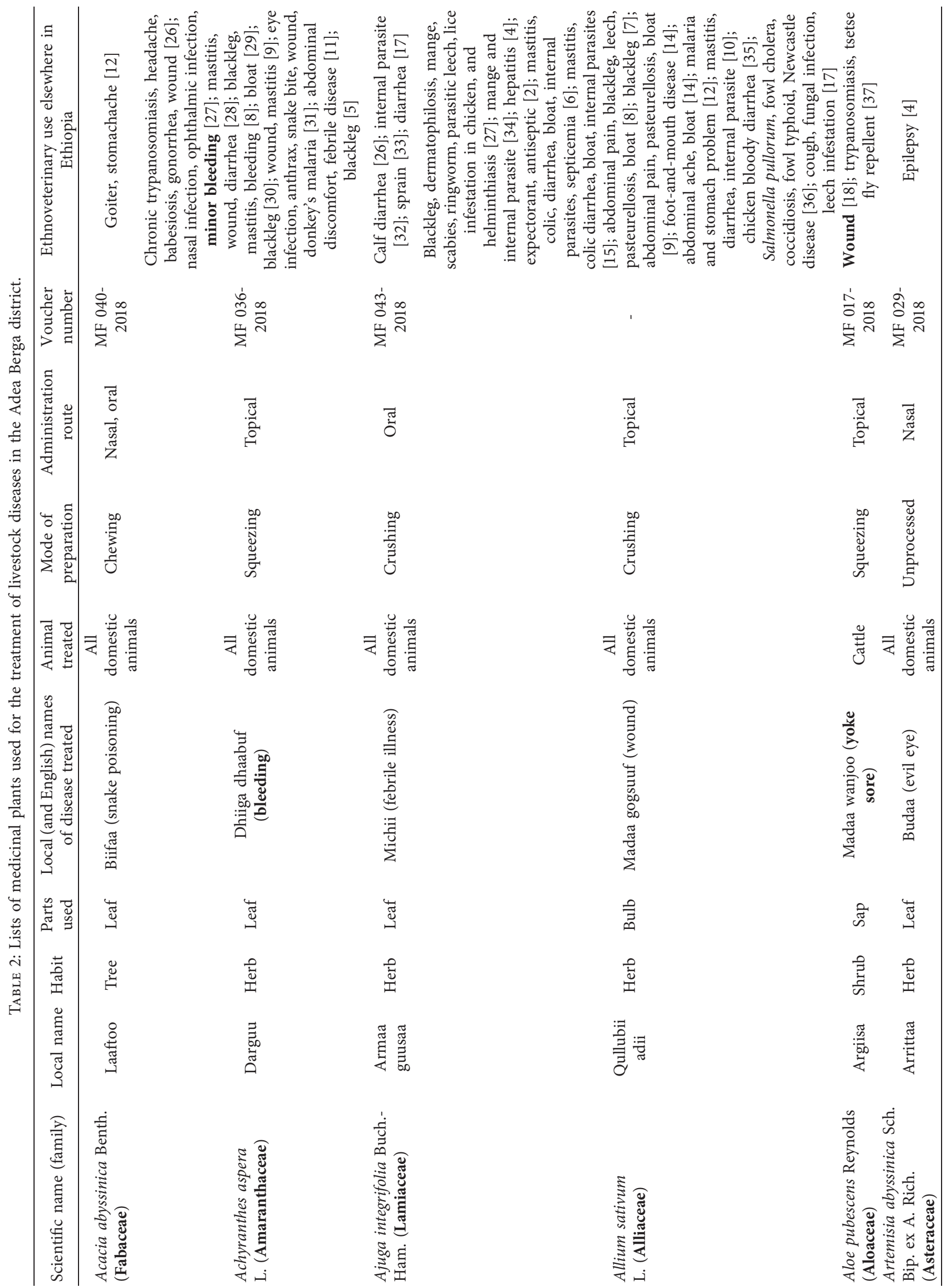




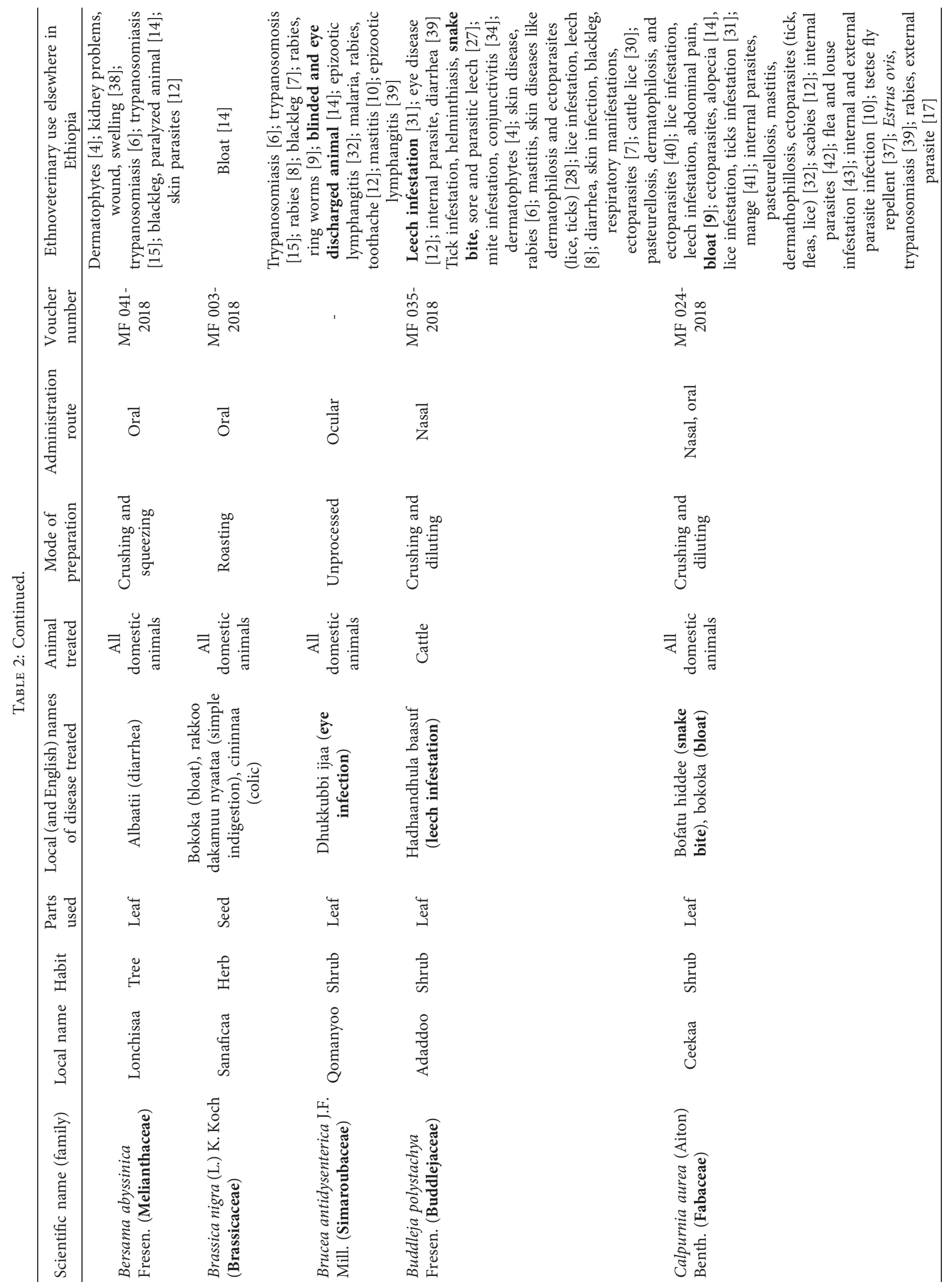




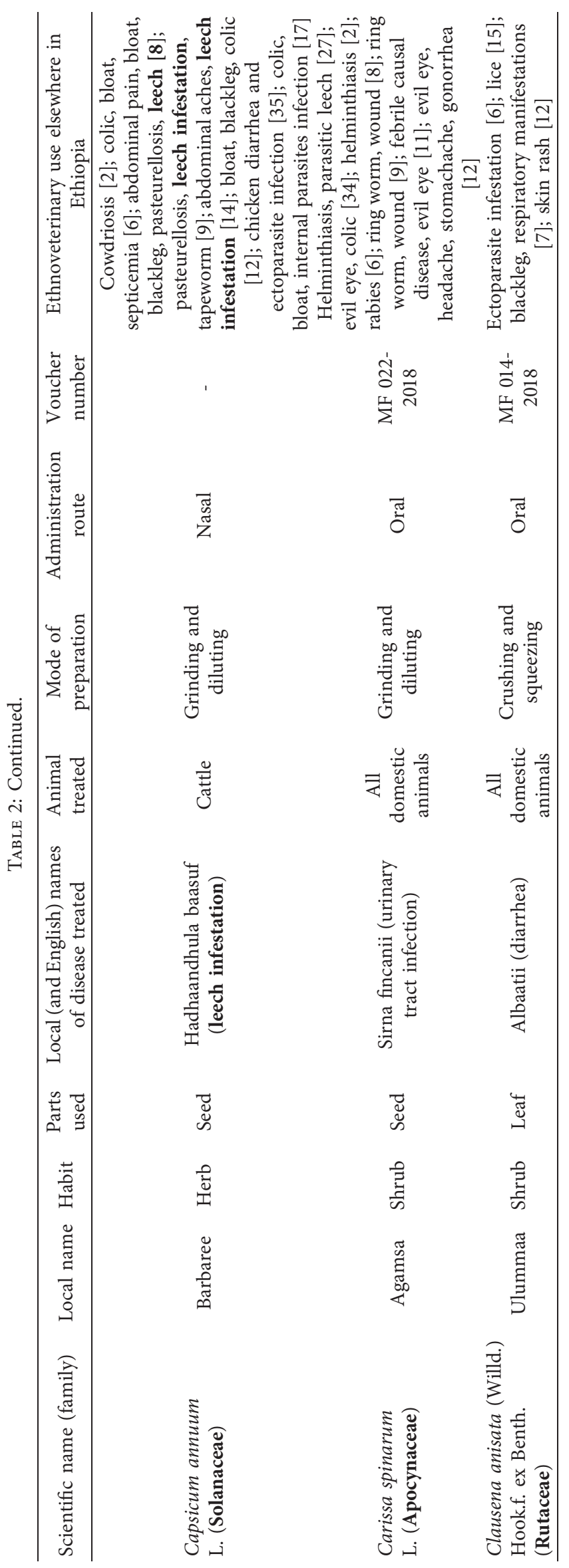




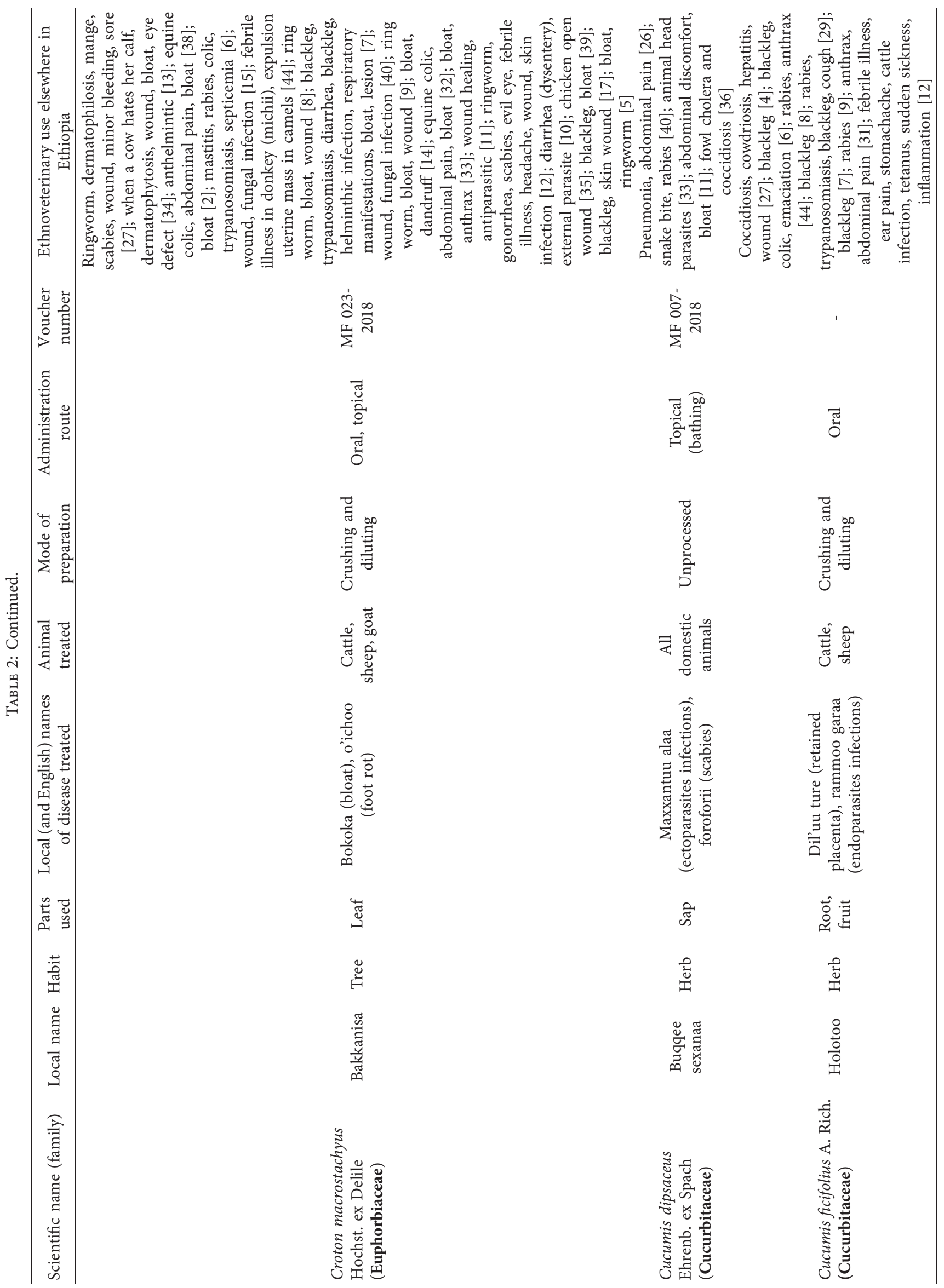




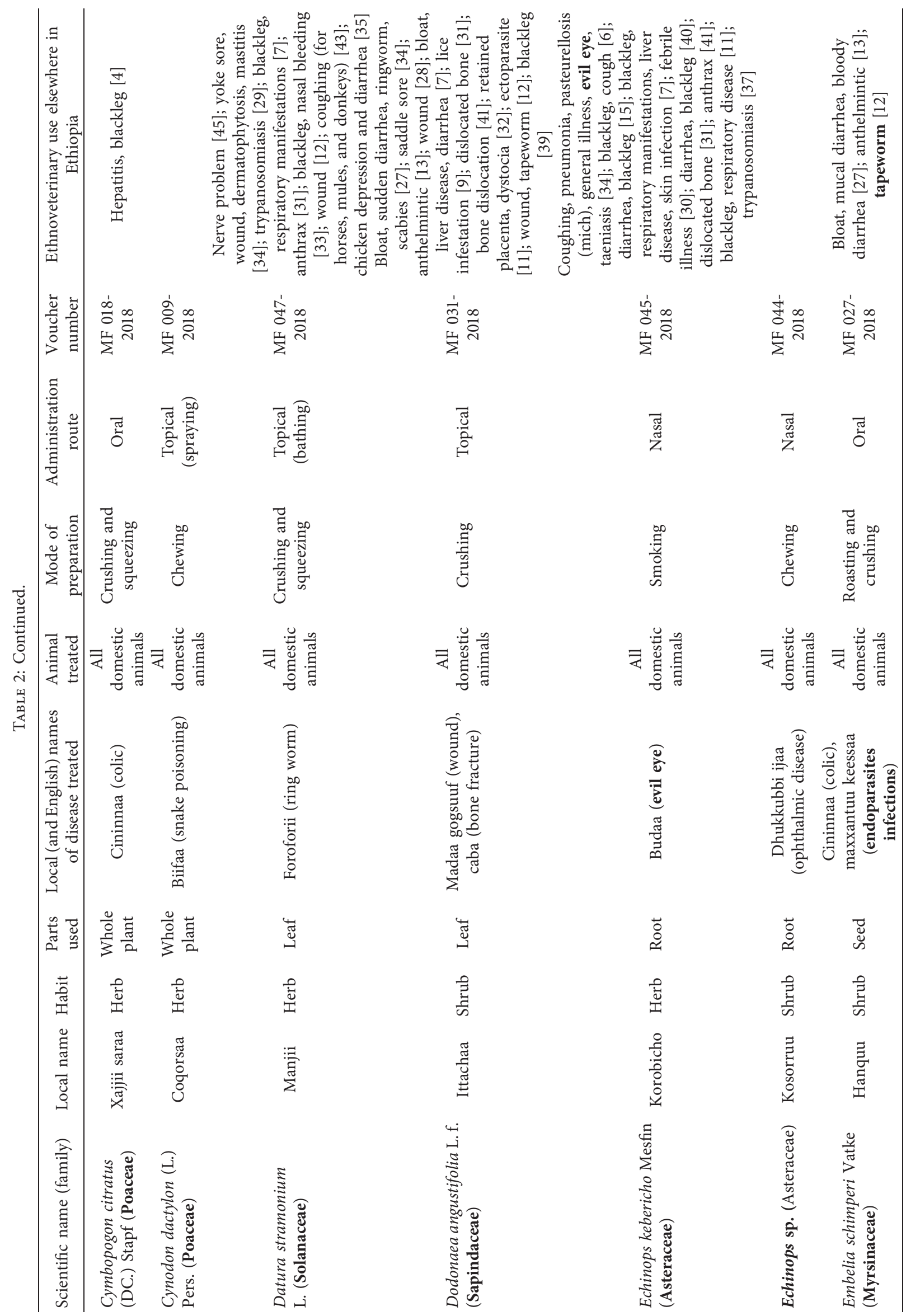




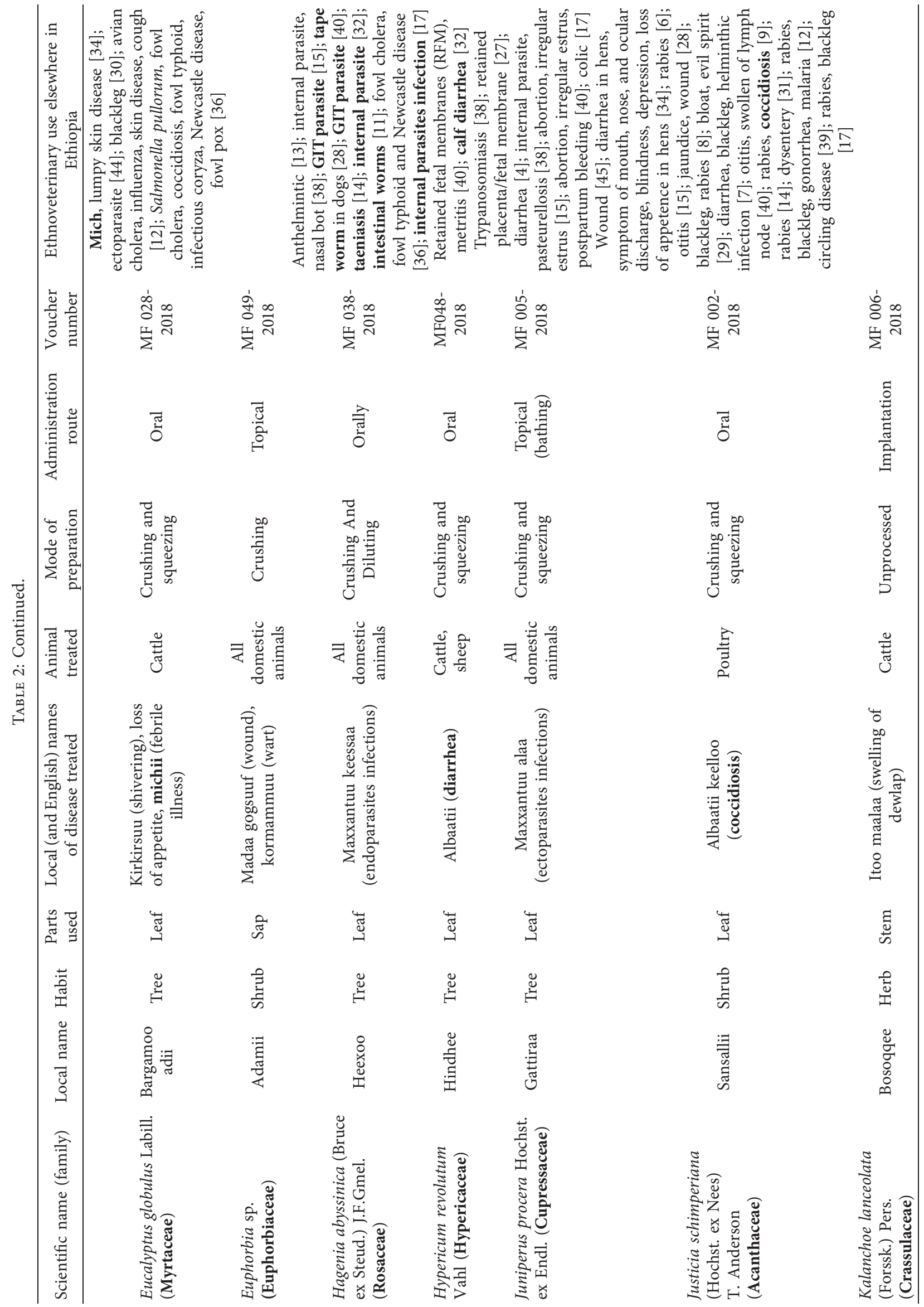




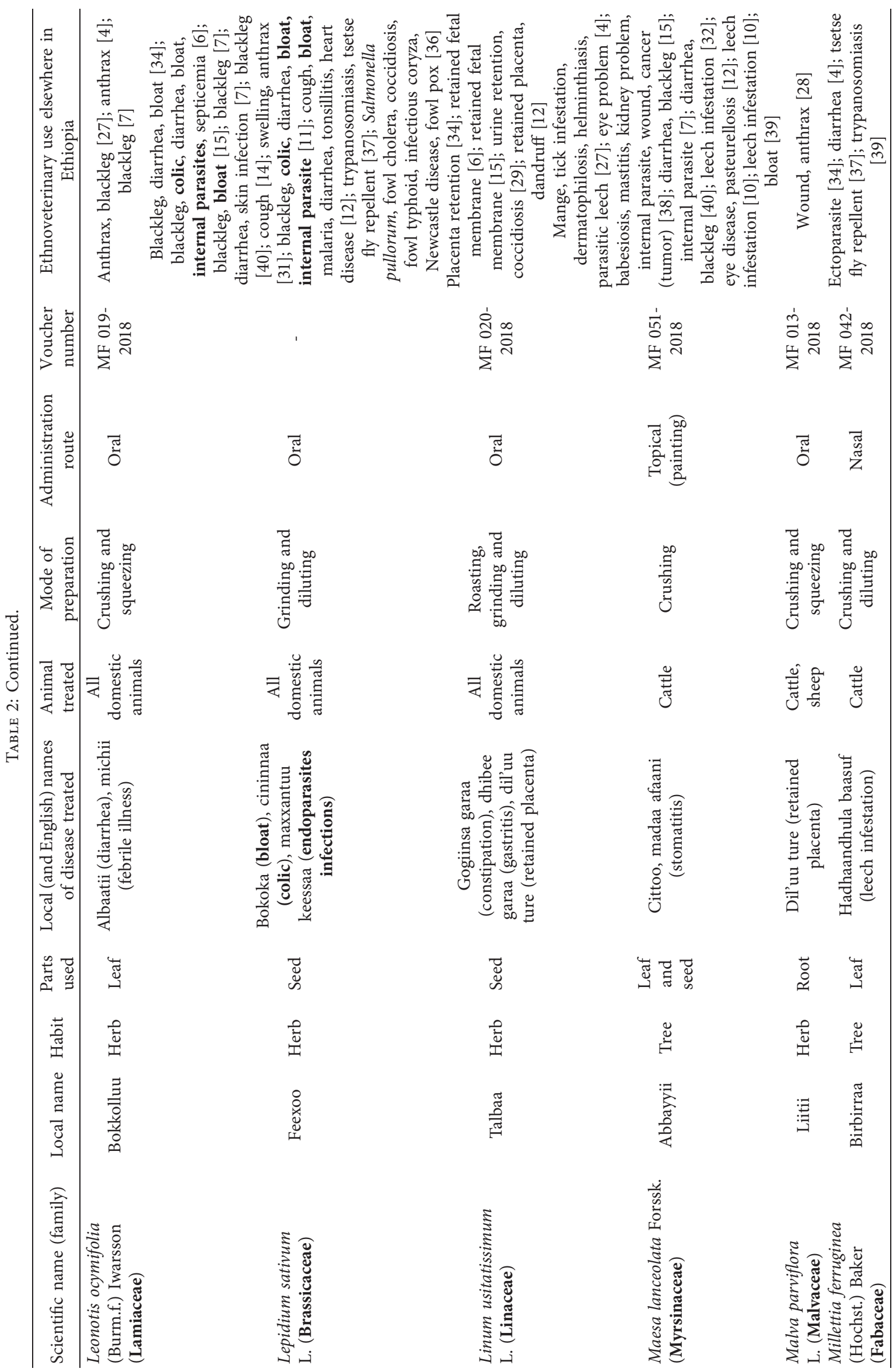




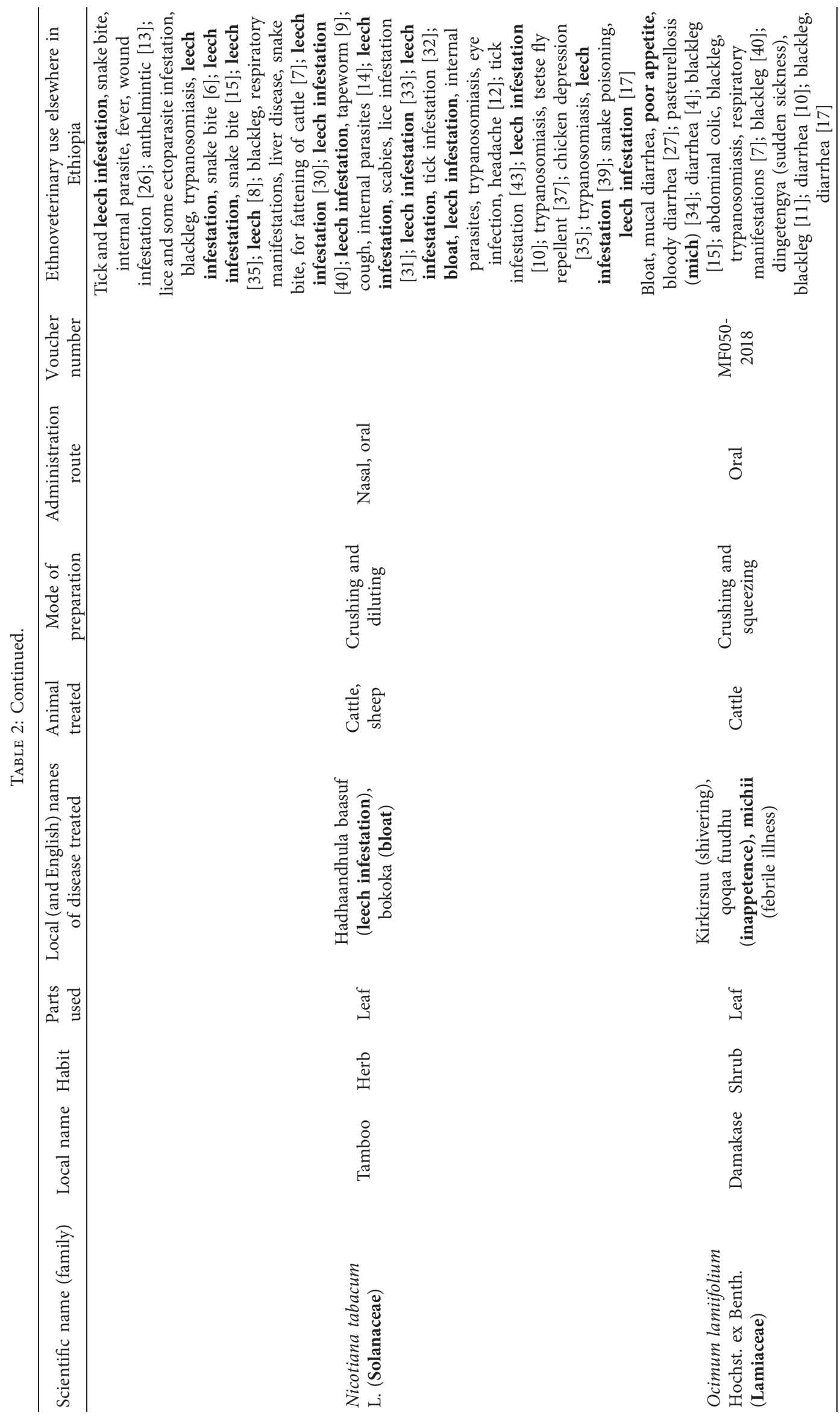




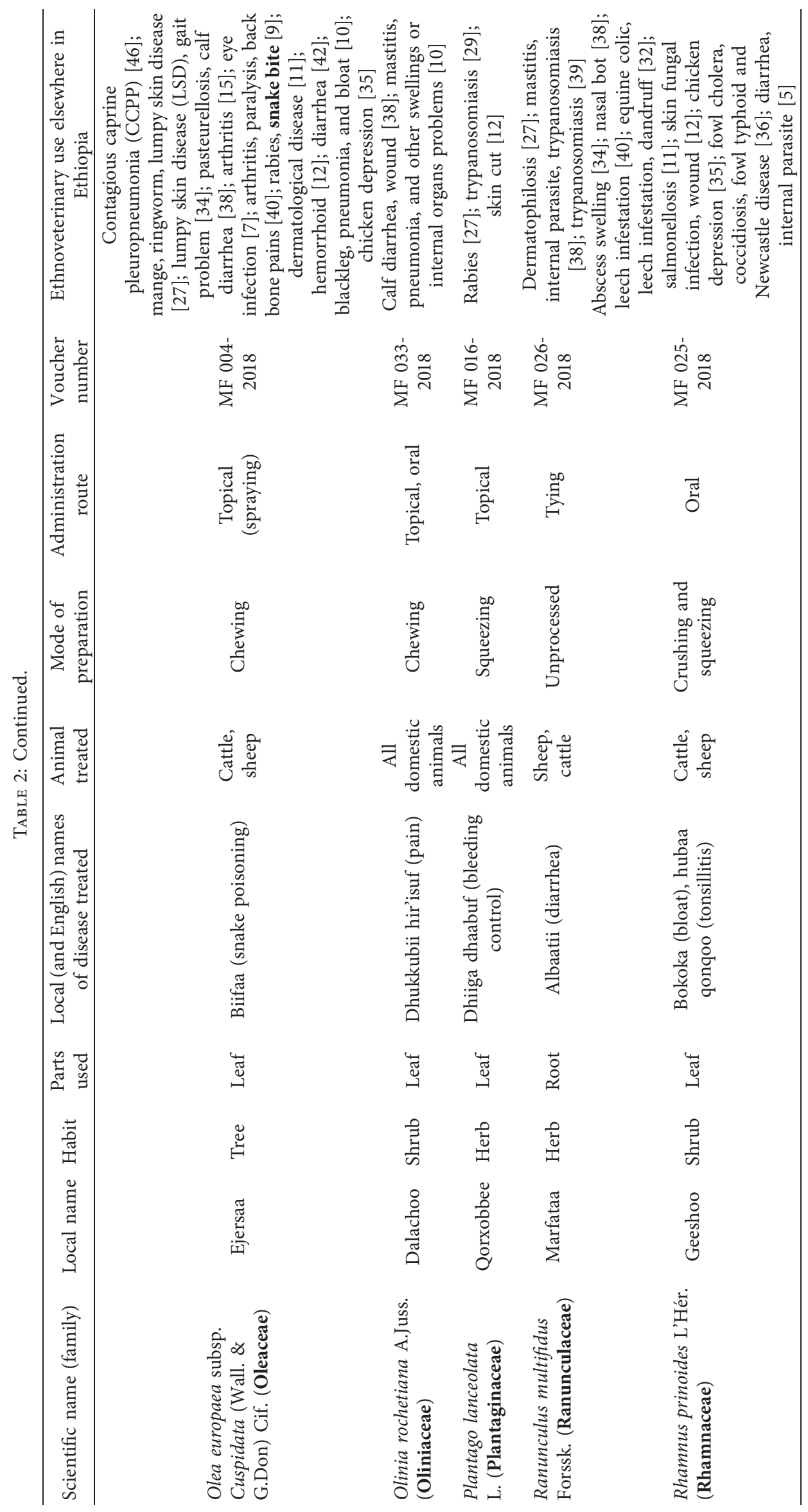




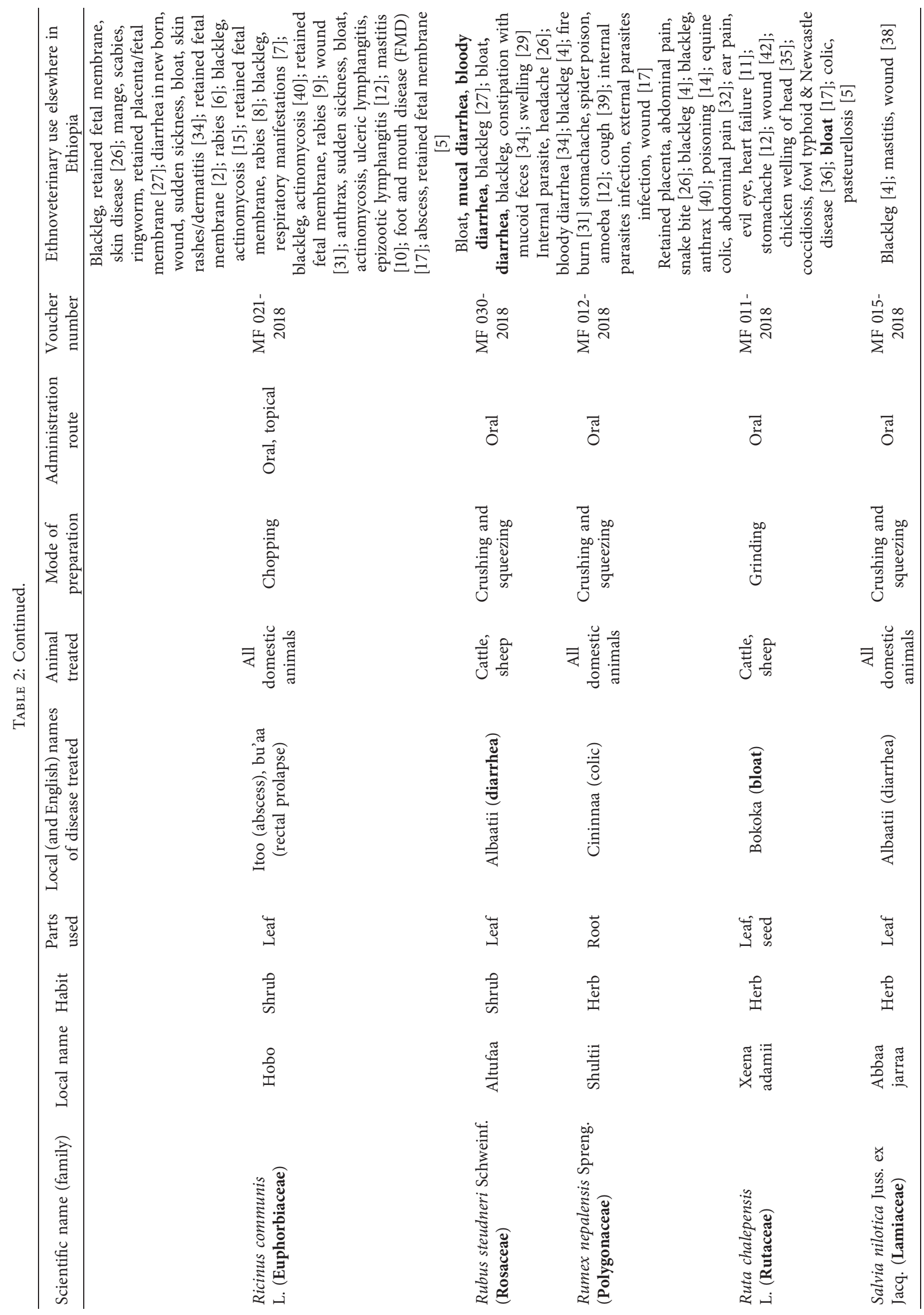




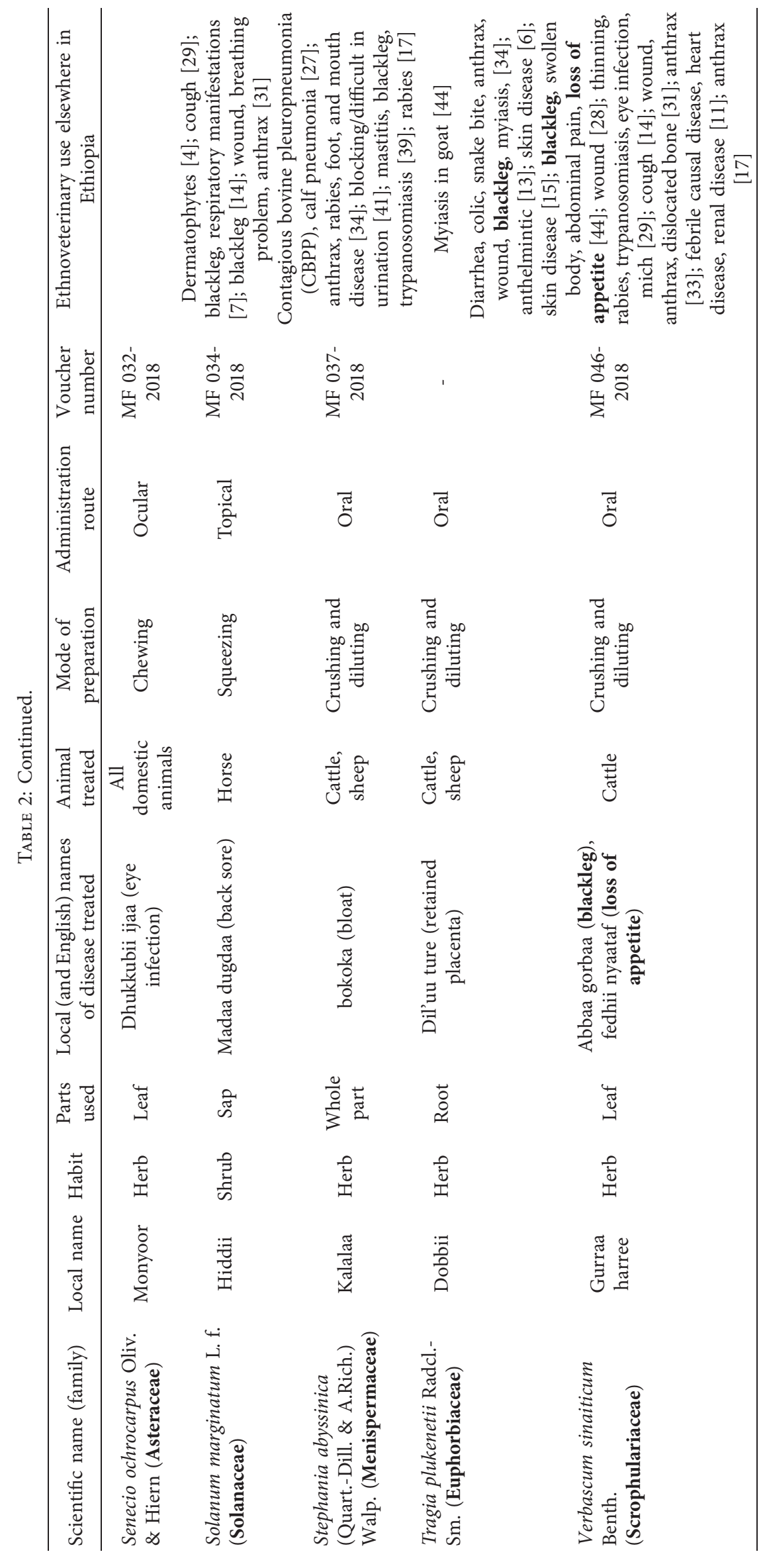




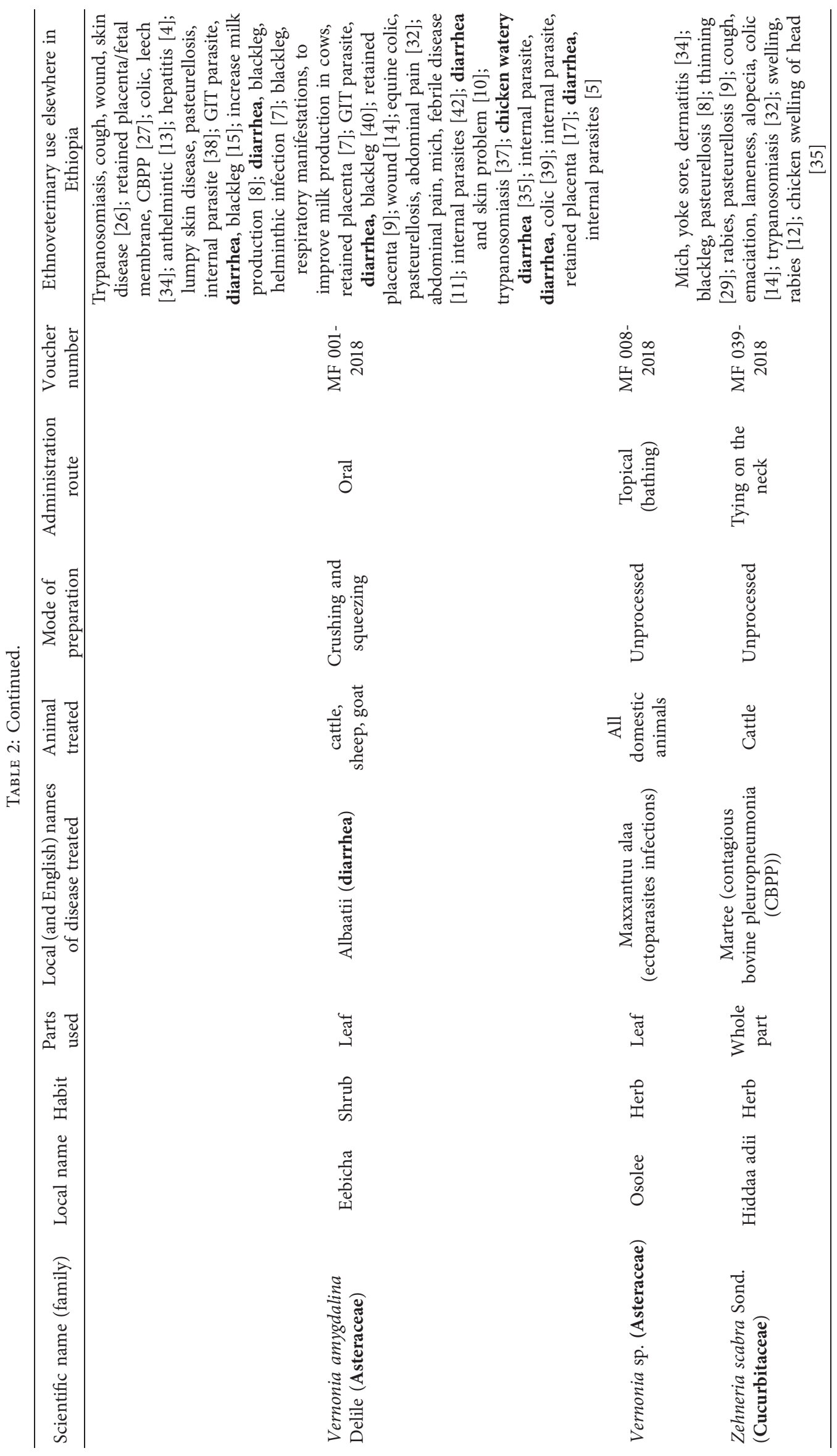




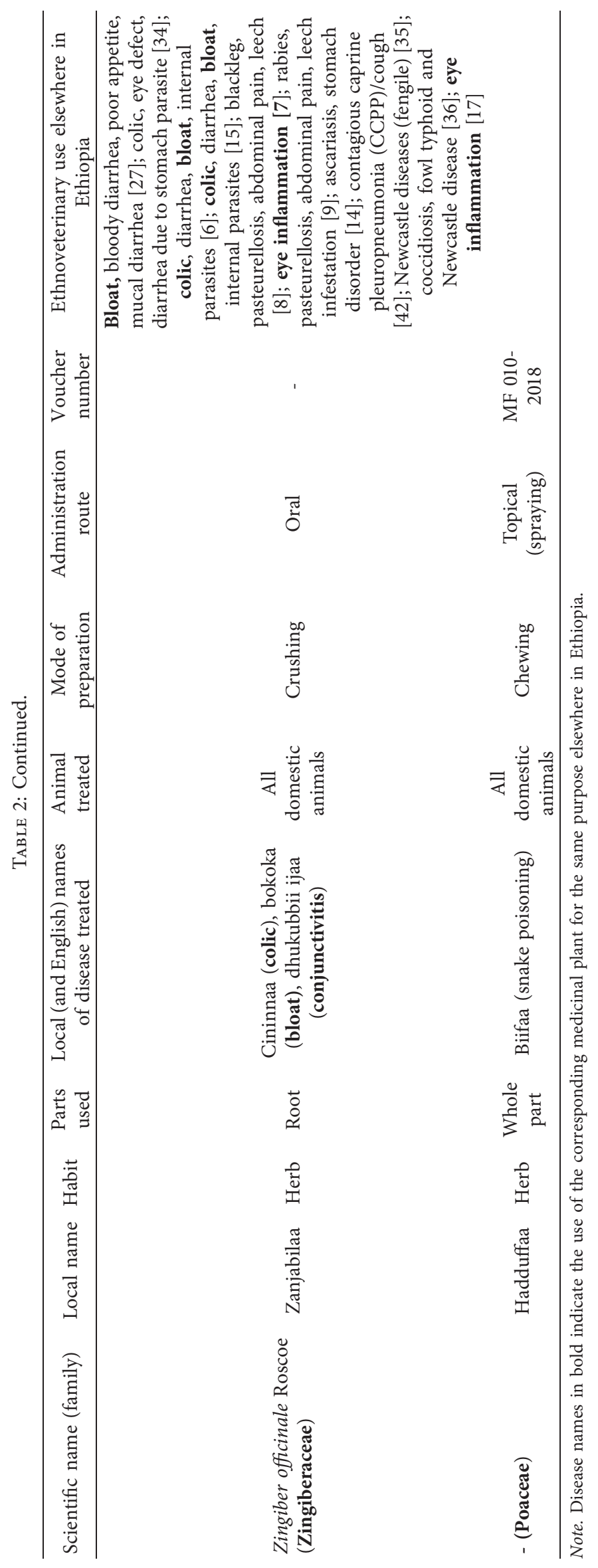




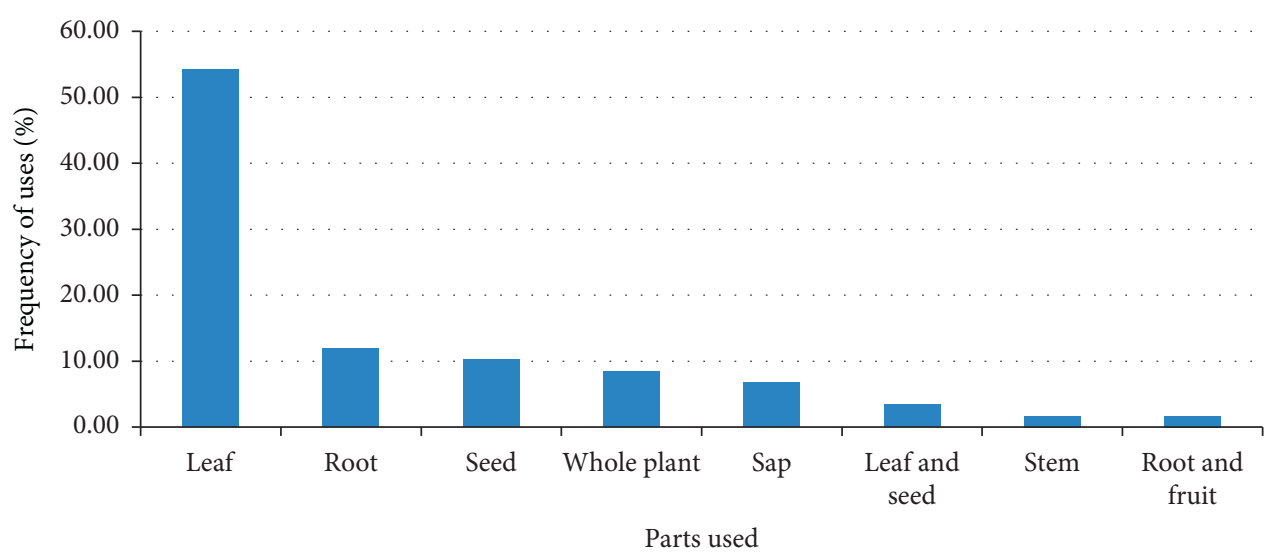

Figure 1: Parts of medicinal plants used in remedy preparation in the Adea Berga district.

TABLE 3: Route of administration of medicinal plants in the Adea Berga district.

\begin{tabular}{lcc}
\hline Route of administration & Frequency & Percent (\%) \\
\hline Oral & 27 & 45.76 \\
Topical & 15 & 25.42 \\
Nasal & 6 & 10.17 \\
Nasal and oral & 3 & 5.08 \\
Oral and topical & 3 & 5.08 \\
Ocular & 2 & 3.39 \\
Tying & 2 & 3.39 \\
Implantation & 1 & 1.69 \\
\hline
\end{tabular}

TABLE 4: Informant consensus factor values for the different ailment categories in the Adea Berga district.

\begin{tabular}{lccc}
\hline Ailment category & Number of plant species & Number of use-reports & ICF value \\
\hline Yoke sore (wound) & 1 & 4 & 1.00 \\
Leech infestation & 4 & 43 & 0.92 \\
Endoparasites infections & 4 & 27 & 0.90 \\
Ectoparasites infections & 4 & 27 & 0.88 \\
Retained placenta & 4 & 35 & 0.88 \\
Snake poisoning & 5 & 10 & 0.88 \\
Evil eye & 2 & 8 & 0.88 \\
Bleeding & 2 & 18 & 0.85 \\
Wound & 4 & 32 & 0.82 \\
Diarrhea & 8 & 35 & 0.77 \\
Bloat & 9 & 22 & 0.76 \\
Colic & 7 & 11 & 0.71 \\
Eye infection & 4 & 0.70 \\
\hline
\end{tabular}

TABLE 5: Rank order priority values of medicinal plants in the Adea Berga district scoring fidelity level values of $80 \%$ or more.

\begin{tabular}{|c|c|c|c|c|c|c|}
\hline Plant name & Ailment category & $I_{\mathrm{U}}$ & $I_{\mathrm{P}}$ & FL value $(100 \%)$ & RPL & ROP \\
\hline Malva parviflora & Retained placenta & 18 & 18 & 100.00 & 1.0 & 100.00 \\
\hline Nicotiana tabacum & Leech infestation & 25 & 25 & 100.00 & 1.0 & 100.00 \\
\hline Calpurnia aurea & Snake poisoning & 24 & 24 & 100.00 & 1.0 & 100.00 \\
\hline Aloe pubescens & Yoke sore & 9 & 9 & 100.00 & 0.7 & 70.00 \\
\hline Senecio ochrocarpus & Eye infection & 11 & 11 & 100.00 & 0.8 & 80.00 \\
\hline Solanum marginatum & Wound & 15 & 13 & 86.66 & 1.0 & 86.66 \\
\hline Cucumis dipsaceus & Ectoparasites & 27 & 24 & 88.89 & 1.0 & 88.89 \\
\hline Vernonia amygdalina & Diarrhea & 20 & 17 & 85.00 & 1.0 & 85.00 \\
\hline
\end{tabular}

Note. $I_{\mathrm{U}}=$ number of informants who mentioned the same plant against any ailment; $I_{\mathrm{P}}=$ number of informants who reported the utilization of medicinal plants against a specific ailment; $\mathrm{FL}=$ fidelity level; $\mathrm{RPL}=$ relative popularity level; $\mathrm{ROP}=$ rank order priority. 
3.8. Habitat of Medicinal Plants. As revealed by the study, most $(59.32 \%)$ of the medicinal plants used in remedy preparation in the study district were gathered from the wild only. Some $(22.04 \%)$ were harvested from homegardens only, and other few were harvested from the wild or homegardens and from the wild or cultivation fields (Figure 2).

\section{Discussion}

4.1. Medicinal Plants Used and Ailments Treated. Livestock keeping is one of the most important economic sources of rural community in the Adea Berga district. Farmers in the district not only depend on plants to get fodder for their animals but also for their use as medicines to manage various livestock ailments as revealed by results of the current study. The study showed the use of 59 medicinal plant species distributed across 35 families to treat 35 livestock ailments. The highest number of medicinal plants used in remedy preparations belonged to the family Asteraceae, and this may be attributed to its dominance in terms of species diversity in the Ethiopian flora. Other studies conducted elsewhere in Ethiopia also reported the highest contribution of Asteraceae to the medicinal flora of the country $[38,47,48]$. The fact that herbs were the most frequently used growth forms in the preparation of remedies could be related to their relatively better abundance in the study district (as also witnessed by the investigators) and also due to their ease of preparation. Many other studies conducted elsewhere in the country also indicated the dominance of herbs in remedy preparations [8, 9, 12, 41, 49-52].

Of the 55 medicinal plants (identified to a species level) used in ethnoveterinary practices in the Adea Berga district, 26 were claimed to be used elsewhere in Ethiopia for other medical conditions not reported by the present study as indicated in Table 2 [2, 4-15, 17, 26-29, 31-40, 42-46], whereas 26 were claimed to be used elsewhere in the country at least once to manage same ailments $[2,5-12,14,15,17,18,26-28,30-34,38-41,44]$. These include Achyranthes aspera (bleeding), Aloe pubescens (wound), Brassica nigra (bloat), Brucea antidysenterica (eye infection), Buddleja polystachya (leech infestation), Calpurnia aurea (snake bite and bloat), Capsicum annuum (leech infestation), Croton macrostachyus (bloat), Dodonaea angustifolia (wound and bone fracture), Echinops kebericho (evil eye), Embelia schimperi (endoparasites infections), Eucalyptus globulus (febrile illness), Hagenia abyssinica (endoparasites infections), Hypericum revolutum (diarrhea), Justicia schimperiana (coccidiosis), Lepidium sativum (bloat, colic, and endoparasites infections), Linum usitatissimum (retained placenta), Nicotiana tabacum (leech infestation and bloat), Ocimum lamiifolium (inappetence and febrile illness), Olea europaea subsp. cuspidata (snake poisoning), Ricinus communis (abscess), Rubus steudneri (diarrhea), Ruta chalepensis (bloat), Verbascum sinaiticum (blackleg and loss of appetite), Vernonia amygdalina (diarrhea), and Zingiber officinale (colic, bloat, and conjunctivitis) (see Table 2). Of these, the most frequently cited medicinal plants include N. tabacum, reported 16 times for its use to treat leech infestation

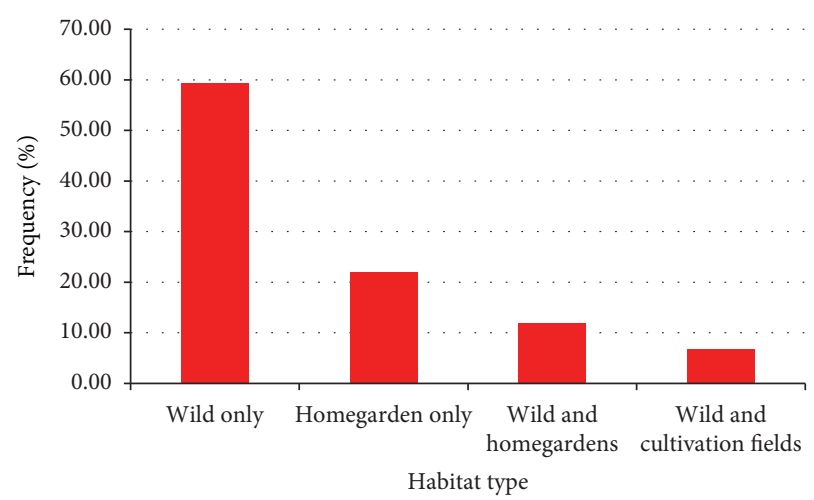

Figure 2: Proportions of medicinal plants harvested from different habitats in the Adea Berga district.

$[6,8-10, \quad 12,14, \quad 15,17, \quad 26, \quad 28, \quad 30-32, \quad 39-41]$; C. macrostachyus, reported 11 times for its use against bloat $[2,5,7-9,14,32-34,38,39] ; H$. abyssinica, reported seven times for its use to treat endoparasites infections $[11,14,15,17,28,32,40]$; L. sativum, reported four times for its use to treat bloat $[11,12,15,34]$; and L. usitatissimum reported four times for its use against retained placenta $[6,12,15,34]$. High consensus among different communities in the use of a given medicinal plant to manage same ailment may indicate its better potency. According to Trotter and Logan [53], pharmacologically effective remedies are expected to have relatively greater informant consensus. In vitro studies conducted on N. tabacum $[54,55]$ revealed the killing effect of its leaf extracts against leeches, the effect of which is caused by an alkaloid called nicotine present in the plant $[56,57]$. An in vivo experiment carried out on the crude extract of $H$. abysinica demonstrated anthelmintic activity against cestodes in goats [58]. The substance kosotoxin present in $H$. abyssinica is believed to be responsible for the anthelmintic activity [59].

The study conducted in the Adea Berga district revealed for the first time the use of three medicinal plants in the Ethiopian ethnoveterinary practices. These include Cynodon dactylon, Kalanchoe lanceolata, and Senecio ochrocarpus that are used to treat snake poisoning, swelling of dewlap, and eye infection, respectively. Literature review revealed that so far, no study, exclusively conducted on medicinal plants of ethnoveterinary importance in the country, has reported the use of such plants.

4.2. Parts Used and Methods of Remedy Preparation and Routes of Administration. The fact that the leaf was the most commonly used medicinal plant part in remedy preparations in the district could be related to its better availability and ease of processing. It could also be due its richness in secondary metabolites [60]. The dominance of leaves in remedy preparations were also reported by studies conducted elsewhere in the country $[61,62]$.

The great majority of the remedies were claimed to be prepared from fresh plant materials, which might be attributed to the year-round availability of the same in the immediate environment. The better preference for fresh 
plant materials in the preparation of remedies was also reported by studies conducted elsewhere in the country [63]. A large proportion of the remedies in the study district were prepared by crushing or squeezing, which could be attributed to its ease of processing. Other studies $[18,31,33,40,64]$ conducted elsewhere in the country also reported crushing as the commonly used method in the preparation of remedies. Availability and its property in dissolving many active compounds could be the reasons for the common use of water as diluent in the preparation remedies in the district as it is also the case in other parts of the country $[18,65,66]$.

Oral is the most frequently employed route of remedy administration in the study district, and this could be related to its environment's suitability for rapid physiological reaction [7, 67]. Other studies conducted elsewhere in the country also reported the common use of oral route in administration of herbal preparations $[4,62]$.

4.3. Informant Consensus Factor, Fidelity Level, and Rank Order Priority Values. The fact that Nicotiana tabacum scored the highest FL and ROP values for its use to treat leech infestation, an ailment that scored the second highest ICF value, may indicate the high preference among informants in the study district for the plant to treat the ailment. Medicinal plants used to manage ailment categories of high ICF values and those of high FL and ROP values are expected to demonstrate good potency and thus are considered to be good candidates for further pharmacological and phytochemical investigations [22, 25]. Nicotiana tabacum is also used elsewhere in Ethiopia for treating leech infestation $[6,26]$. In vitro investigation of leaf extracts of Nicotiana tabacum demonstrated activity against leeches $[54,55,68]$, which could be attributed to the presence of nicotine in the leaf extract that interacts with nicotinic acetylcholine receptors to cause muscle weakness [55]. The other plant Calpurnia aurea that scored the highest FL and ROP values for its use to treat snake poisoning in the study district is also used elsewhere in the country against same ailments [27].

4.4. Comparison of Medicinal Plant Knowledge between Different Social Groups. Results of the present study indicate that the great majority of respondents selected for interviews in the study district were males. This may reflect the fact that males are the most favored by practitioners in the district in the transfer of traditional medical knowledge across generations. Other studies conducted elsewhere in the country also showed the dominance of males in traditional medical practices $[7,18,69]$. The majority of the participants selected for participation in ethnoveterinary study in the district were illiterate. This may reveal the fact that illiterate people are more knowledgeable as they are less exposed to cultural change compared with literate ones. Other studies carried out in other parts of the country also revealed that illiterate people held better traditional medical knowledge than literate ones $[7,27]$.
4.5. Habitats of Medicinal Plants. As shown by the study, the majority of the medicinal plants used in remedy preparations in the study district were harvested from the wild, an indication of the little practice of cultivating medicinal plants in the study district. The common use of plants harvested from the wild was also reported by other studies conducted elsewhere in the country $[31,47,62,70,71]$.

\section{Conclusion}

The results of the present study revealed the high dependence of people in the Adea Berga district in the use of medicinal plants to manage livestock ailments, which could be due to the high prevalence of different diseases, limited access to modern veterinary care facilities, high prices of modern drugs, and diversity of local flora. Based on the demographic characteristic of people who participated in the study, knowledge on herbal medicine is mainly held by males and illiterate people. Priority for further pharmacological and phytochemical investigations needs to be given to the plants Nicotiana tabacum, Malva parviflora, and Calpurnia aurea that scored the highest FL and ROP values for their uses to treat leech infestation, retained placenta, and snake poisoning, respectively, as such values may indicate their higher potency against the respective ailments. Urgent action is needed to conserve Aloe pubescens, an Ethiopian endemic plant that has been included in the IUCN Red List as "near-threatened" species. Aloe pubescens is among the five medicinal plants in the study area that scored the highest FL value.

\section{Data Availability}

Ethnoveterinary data were stored in a computer available at the Aklilu Lemma Institute of Pathobiology (ALIPB), Addis Ababa University (AAU), and the Faculty of Veterinary Medicine, Hawassa University. Readers may request the institutions for permission to get access to the data.

\section{Conflicts of Interest}

The authors declare that they have no conflicts of interest.

\section{Acknowledgments}

The authors thank the Office of the Vice President for Research and Technology Transfer of Addis Ababa University for its support in financing field trip expenses. The authors are also grateful to the informants in the Adea district who unreservedly shared with us their knowledge on medicinal plants used in ethnoveterinary practices and to district officials and experts who facilitated the ethnobotanical data collection work and for provision of data on major livestock health problems and available veterinary healthcare facilities in the district. The research was financially supported by the Office of the Vice President for Research and Technology Transfer of Addis Ababa University (grant number: TR/036/2016). The role of the Office is supporting academic staff and students to conduct problem-solving research and publish their findings. 


\section{References}

[1] G. Abraha, "Major animal health problems of market Oriented livestock development in atsbi Womberta woreda, Tigray regional state," DVM thesis, Addis Ababa University, Addis Ababa, Ethiopia, 2007.

[2] T. Sori, M. Bekana, G. Adugna, and K. Kelbessa, "Medicinal plants in the ethnoveterinary practices of Borana pastoralists, Southern Ethiopia," The International Journal of Applied Research in Veterinary Medicine (IJARVM), vol. 2, pp. 220-225, 2004.

[3] D. Abebe and A. Ayehu, Medicinal Plants and Enigmatic Health Practices of Northern Ethiopia, Addis Ababa: B.S.P.E, Addis Ababa, Ethiopia, 1993.

[4] H. Yineger, E. Kelbessa, T. Bekele, and E. Lulekal, "Ethnoveterinary medicinal plants at Bale Mountains National Park, Ethiopia," Journal of Ethnopharmacology, vol. 112, no. 1, pp. 55-70, 2007.

[5] A. Bekele and A. Mussa, "Ethnoveterinary practice in Chiro district, Western Hararge, Ethiopia," Pharmacologyonline, vol. 1, pp. 128-139, 2009.

[6] F. Tamiru, W. Terfa, E. Kebede, G. Dabessa, R. K. Roy, and M. Sorsa, "Ethnoknowledge of plants used in veterinary practices in Dabo Hana district, West Ethiopia," Journal of Medicinal Plants Research, vol. 7, pp. 2960-2971, 2013.

[7] Y. Yigezu, D. B. Haile, and W. Y. Ayen, "Ethnoveterinary medicines in four districts of Jimma zone, Ethiopia: cross sectional survey for plant species and mode of use," $B M C$ Veterinary Research, vol. 10, no. 1, p. 76, 2014.

[8] B. Tadesse, G. Mulugeta, G. Fikadu, and A. Sultan, "Survey on ethno-veterinary medicinal plants in selected woredas of East Wollega zone, Western Ethiopia," Journal of Biology, Agriculture and Healthcare, vol. 4, p. 17, 2014.

[9] T. Birhanu and D. Abera, "Survey of ethno-veterinary medicinal plants at selected Horro Gudurru districts, western Ethiopia," African Journal of Plant Science, vol. 9, pp. 185-192, 2015.

[10] G. Romha, T. A. Dejene, L. B. Telila, and D. F. Bekele, "Ethnoveterinary medicinal plants: preparation and application methods by traditional healers in selected districts of southern Ethiopia," Veterinary World, vol. 8, no. 5, pp. 674-684, 2015.

[11] C. Mohammed, D. Abera, M. Woyessa, and T. Birhanu, "Survey of ethno-veterinary medicinal plants in Melkabello district, eastern Harerghe zone, eastern Ethiopia," Ethiopian Veterinary Journal, vol. 20, pp. 1-15, 2016.

[12] G. Kitata, D. Abdeta, and M. Amante, "Ethnoknowledge of plants used in veterinary practices in Midakegn district, west Showa of Oromia region, Ethiopia," Journal of Medicinal Plants Studies, vol. 5, pp. 282-288, 2017.

[13] C. E. Scantlebury, L. Peachey, J. Hodgkinson et al., "Participatory study of medicinal plants used in the control of gastrointestinal parasites in donkeys in Eastern Shewa and Arsi zones of Oromia region, Ethiopia," BMC Veterinary Research, vol. 9, no. 1, p. 179, 2013.

[14] T. F. Feyissa, M. M. Shigut, T. B. Hailemariam, T. Regassa, and N. K. Kergano, "Ethnobotanical study of ethnoveterinary plants in Kelem Wollega zone, Oromia region, Ethiopia," Journal of Medicinal Plants Research, vol. 11, pp. 307-317, 2017.

[15] F. B. Bayecha, D. L. Hordofa, D. G. Nurfeta, and R. A. Abebe, "Survey of ethno-veterinary medicinal plants at Dale Sadi districts of Oromia regional state, western Ethiopia," Journal of Natural Sciences Research, vol. 8, p. 19, 2018.
[16] T. T. Jima, "Medicinal plants used in the treatment of livestock diseases in Berbere district of Bale zone, Oromia region, Ethiopia," Journal of Medicinal Plants Research, vol. 12, pp. 270-277, 2018.

[17] Y. Abera and B. Mulate, "Ethno-veterinary medicine: a potential alternative to animal health delivery in Wolmera district, Oromia Region, Ethiopia," Ethiopian Veterinary Journal, vol. 23, no. 1, pp. 111-130, 2019.

[18] M. Berhanu, T. Tintagu, S. Fentahun, and M. Giday, "Ethnoveterinary survey of medicinal plants used for treatment of animal diseases in Ambo District of Oromia Regional State of Ethiopia," Evidence-Based Complementary and Alternative Medicine, vol. 202012 pages, Article ID 8816227, 2020.

[19] T. Serekebrhan, G. Animut, Y. Mekasha, and G. Assefa, "Assessment of farmers perception towards production and utilization of improved forages for dairy cattle feeding in the central highlands of Ethiopia," East African Journal of Veterinary and Animal Sciences, vol. 2, pp. 45-56, 2018.

[20] S. Diro, Assessing the Effect of Plant Density on Yield of Irrigated Potato and Analysis of Input Supply Chains at Adea Berga District, MSc thesis, Ambo University, Ambo, Ethiopia, 2016.

[21] G. J. Martin, Ethnobotany: A Method Manual, Chapman \& Hall, London, UK, 1995.

[22] J. Friedman, Z. Yaniv, A. Dafni, and D. Palewitch, "A preliminary classification of the healing potential of medicinal plants, based on a rational analysis of an ethnopharmacological field survey among Bedouins in the Negev Desert, Israel," Journal of Ethnopharmacology, vol. 16, no. 2-3, pp. 275-287, 1986.

[23] M. S. Ali-Shtayeh, R. M. Jamous, and R. M. Jamous, "Traditional Arabic Palestinian ethnoveterinary practices in animal health care: a field survey in the West Bank (Palestine)," Journal of Ethnopharmacology, vol. 182, pp. 35-49, 2016.

[24] M. Giday, Z. Asfaw, Z. Woldu, and T. Teklehaymanot, "Medicinal plant knowledge of the Bench ethnic group of Ethiopia: an ethnobotanical investigation," Journal of Ethnobiology and Ethnomedicine, vol. 5, no. 1, p. 34, 2009.

[25] M. Heinrich, A. Ankli, B. Frei, C. Weimann, and O. Sticher, "Medicinal plants in Mexico: healers' consensus and cultural importance," Social Science \& Medicine, vol. 47, no. 11, pp. 1859-1871, 1998.

[26] Y. Tekle, "Study on ethno veterinary practices in Amaro special district Southern Ethiopia," Medicinal \& Aromatic Plants, vol. 4, p. 2, 2015 b.

[27] E. Lulekal, Z. Asfaw, E. Kelbessa, and P. Van Damme, "Ethnoveterinary plants of ankober district, North Shewa zone, Amhara region, Ethiopia," Journal of Ethnobiology and Ethnomedicine, vol. 10, no. 1, p. 21, 2014.

[28] G. Gebrezgabiher, S. Kalayou, and S. Sahle, "An ethno-veterinary survey of medicinal plants in woredas of Tigray region, Northern Ethiopia," International Journal of Biodiversity and Conservation, vol. 5, pp. 89-97, 2013.

[29] Y. S. Birhan, S. L. Kitaw, Y. A. Alemayehu, and N. M. Mengesha, "Ethnoveterinary medicinal plants and practices in Enarj Enawga district, East Gojjam zone, Amhara region, Ethiopia," International Journal of Animal Sciences, vol. 2, p. 1014, 2018.

[30] H. Tedila and G. Dida, "Ethnobotanical study of traditional medicinal plants used for treatment of human and livestock ailments by traditional healers in Goba woreda, Bale zone, Oromia, South East Ethiopia," Journal of Natural Sciences Research, vol. 9, p. 10, 2019.

[31] A. Teklay, "Traditional medicinal plants for ethnoveterinary medicine used in kilte awulaelo district, tigray region, 
northern Ethiopia," Journal of Biology, Agriculture and Healthcare, vol. 5, p. 19, 2015.

[32] Y. Tekle, "An ethno-veterinary botanical survey of medicinal plants in kochore district of gedeo zone, southern nations nationalities and peoples regional state (SNNPRs), Ethiopia," Journal of Scientific and Innovative Research, vol. 3, pp. 433-445, 2014.

[33] G. Yirga, M. Teferi, G. Brhane, and S. Amare, "Plants used in ethnoveterinary practices in Medebay-Zana district, Northern Ethiopia," Journal of Medicinal Plants Research, vol. 6, pp. 433-438, 2012.

[34] A. Mengesha and D. Dessie, "Ethno veterinary medicine knowledge and practices in and around Gondar, Ethiopia," Journal of Public Health, Pharmacy and Pharmacology, vol. 3, pp. 39-68, 2018.

[35] Y. W. Wodegebriel, B. F. Abebe, and A. Tamir, "Medicinal plants used by farmers for treatment of major diseases of chicken in South Wollo zone, Amhara region, Ethiopia," International Journal of Advanced Research in Biological Sciences, vol. 5, pp. 45-58, 2018.

[36] S. Markos, "Ethno veterinary medicine and common diseases of chicken producers in western zone of tigray, northern Ethiopia," Journal of Agriculture and Ecology Research International, vol. 20, pp. 1-17, 2019.

[37] B. E. Endalachew, "Practices of ethnoveterinary against animal trypanosomosis in Southern Ethiopia," Global Journal of Biological and Biomedical Research, vol. 3, pp. 132-136, 2015.

[38] Y. Tekle, "Medicinal plants in the ethno veterinary practices of Bensa woreda, Southern Ethiopia," OALibrary, vol. 2, no. 1, pp. 1-12, 2015.

[39] M. M. Moliso, F. Tessema, M. Yilma, T. Getachew, and M. Asrat, "Documentation of ethno veterinary practices in selected sites of wolaita and dawuro zones, Ethiopia," Global Journal of Science Frontier Research: D Agriculture and Veterinary, vol. 16, p. 5, 2016.

[40] A. Usmane, T. Birhanu, M. Redwan, E. Sado, and D. Abera, "Survey of ethno-veterinary medicinal plants at selected districts of Harari Regional State, Eastern Ethiopia," Ethiopian Veterinary Journal, vol. 20, no. 1, pp. 1-22, 2016.

[41] A. Osman, D. B. Sbhatu, and M. Giday, "Medicinal plants used to manage human and livestock ailments in raya kobo district of amhara regional state, Ethiopia," Evidence-Based Complementary and Alternative Medicine, vol. 202019 pages, Article ID 1329170, 2020.

[42] M. Mengistu, E. Kebede, and B. Serda, "Ethnobotanical knowledge of pastoral community for treating livestock diseases in Shinle zone, Somali regional state, Eastern Ethiopia," Journal of Veterinary Science \& Technology, vol. 8, no. 5, p. 5, 2017.

[43] K. Tolossa, E. Debela, S. Athanasiadou, A. Tolera, G. Ganga, and J. G. Houdijk, "Ethno-medicinal study of plants used for treatment of human and livestock ailments by traditional healers in South Omo, Southern Ethiopia," Journal of Ethnobiology and Ethnomedicine, vol. 9, no. 1, p. 32, 2013.

[44] A. Kebede, S. Ayalew, A. Mesfin, and G. Mulualem, "An ethnoveterinary study of medicinal plants used for the management of livestock ailments in selected kebeles of dire dawa administration, eastern Ethiopia," Journal of Plant Sciences, vol. 5, pp. 34-42, 2017.

[45] M. Giday and T. Teklehaymanot, "Ethnobotanical study of plants used in management of livestock health problems by Afar people of Ada'ar District, Afar Regional State, Ethiopia," Journal of Ethnobiology and Ethnomedicine, vol. 9, no. 1, p. 8, 2013.
[46] K. Gebrehiwot and M. Shumbahri, "An ethnoveterinary survey of medicinal plants used to treat livestock diseases in Abala, northeastern Ethiopia," Journal of Basic and Applied Research International, vol. 10, pp. 185-193, 2015.

[47] B. Taddese, D. Abera, and E. Ejeta, "Ethnobotanical study of medicinal plants in selected Horro Gudurru woredas, western Ethiopia," Journal of Biology, Agriculture and Healthcare, vol. 5, p. 1, 2015.

[48] G. Chekole, "Ethnobotanical study of medicinal plants used against human ailments in Gubalafto District, Northern Ethiopia," Journal of Ethnobiology and Ethnomedicine, vol. 13, no. 1, p. 55, 2017.

[49] D. Hunde, "Use and management of traditional plants by indigenous people of Boosat district Welenchiti area," MSc Thesis, Addis Ababa University, Addis Ababa, Ethiopia, 2001.

[50] E. Amenu, "Use and management of medicinal plants by indigenous people of Ejaji area (Chelya Wereda) west Shewa, Ethiopia: an ethnobotanical approach," MSc Thesis, Addis Ababa University), Addis Ababa, Ethiopia, 2007.

[51] M. Adefa and B. Abraha, "Ethnobotanical survey of traditional medicinal plants in Tehuledere district, south Wollo, Ethiopia," Journal of Medicinal Plants Research, vol. 5, pp. 6233-6242, 2011.

[52] M. Adefa and S. Getaneh, "Medicinal plants biodiversity and local healthcare management system in Chencha district; Gamo Gofa, Ethiopia," Journal of Pharmacognosy and Phytotherapy, vol. 2, p. 1, 2013.

[53] R. T. Trotter and M. H. Logan, "Informants consensus: a new approach for identifying potentially effective medicinal plants," in Plants in Indigenous Medicine and Diet, N. R. Etkin, Ed., pp. 91-112, Redgrave Publishing Company, New York, NY, USA, 1986.

[54] M. Bahmani, T. Farkhondeh, and P. Sadighara, "The antiparasitic effects of Nicotina tabacum on leeches," Comparative Clinical Pathology, vol. 21, no. 3, pp. 357-359, 2012.

[55] E. O. Ogello, E. M. Kembenya, K. O. Obiero, and J. M. Munguti, "Effects of Nicotina tobacum (Linnaeus) on the survival and behavioral response of the freshwater leeches, Hirudinaria sp," International Journal of Aquatic Science, vol. 7, pp. 19-24, 2016.

[56] M. K. Bahmani and E. Banihabib, "Comparative assessment of the antiannelida (Limnatis nilotica) activity of nicotine with niclosamide," Global Veterinaria, vol. 10, pp. 153-157, 2013.

[57] M. Bahmani, S. A. Karamati, E. Banihabib, and K. Saki, "Comparison of effect of nicotine and levamisole and ivermectin on mortality of leech," Asian Pacific Journal of Tropical Disease, vol. 4, no. Suppl 477, p. S480, 2014.

[58] G. Abebe, L. J. Dawson, G. Detweiler, T. A. Gipson, and T. Sahlu, "Hagenia abyssinica (Kosso) for internal parasite control in goats," in Proceedings of a conference the opportunities and challenges of enhancing goat production in East Africa, Awassa, 2000. (E (Kika) de la Garza Institute for Goat Research, M. R. Merkel, G. Abebe, and A. L. Goetsch, Eds., pp. 190-195, Langston University, Langston, OK, USA, 2000.

[59] H. Thomsen, K. Reider, K. Franke et al., "Characterization of constituents and anthelmintic properties of Hagenia abyssinica," Scientia Pharmaceutica, vol. 80, no. 2, pp. 433-446, 2012.

[60] N. Amsalu, Y. Bezie, M. Fentahun, A. Alemayehu, and G. Amsalu, "Use and conservation of medicinal plants by indigenous people of gozamin wereda, East gojjam zone of amhara region, Ethiopia: an ethnobotanical approach," Evidence-Based Complementary and Alternative Medicine, vol. 201823 pages, Article ID 2973513, 2018. 
[61] A. M. Eshete, E. Kelbessa, and G. Dalle, "Ethnobotanical study of medicinal plants in guji agro-pastoralists, blue hora district of Borana zone, Oromia region, Ethiopia," Journal of $\mathrm{Me}$ dicinal Plants Studies, vol. 4, pp. 170-184, 2016.

[62] K. Atinafu, A. Shimels, M. Akalu, and M. Getachew, "An ethnoveterinary study of medicinal plants used for the management of livestock ailments in selected kebeles of dire dawa administration, eastern Ethiopia," Journal of Plant Sciences, vol. 5, pp. 34-42, 2017.

[63] B. Yemane, Y. Berhane, and D. K. Surender Reddy, "Ethnobotanical study of medicinal plants in sub region logo anseba, region gash barka, Eritrea," IOSR Journal of Pharmacy and Biological Sciences, vol. 11, no. 04, pp. 63-73, 2016.

[64] A. Belayneh, Z. Asfaw, S. Demissew, and F. Bussa, "Medicinal plants potential and use by pastoral and agro-pastoral communities in Erer Valley of Babile Woreda, Eastern Ethiopia," Journal of Ethnobiology and Ethnomedicine, vol. 8, pp. 12-16, 2012.

[65] M. Giday, Z. Asfaw, T. Elmqvist, and Z. Woldu, "An ethnobotanical study of medicinal plants used by the Zay people in Ethiopia," Journal of Ethnopharmacology, vol. 85, no. 1, pp. 43-52, 2003.

[66] T. Feyera, E. Mekonnen, B. U. Wakayo, and S. Assefa, "Botanical ethnoveterinary therapies used by agro-pastoralists of Fafan zone, Eastern Ethiopia," BMC Veterinary Research, vol. 13, no. 1, p. 232, 2017.

[67] H. Atnafu, T. Awas, S. Alemu, and S. Wube, "Ethnobotanical study of medicinal plants in selale mountain ridges, North Shoa, Ethiopia," Biodiversity International Journal, vol. 2, pp. 567-577, 2018.

[68] M. N. Wan Norhana, B. C. Kua, and R. Liyana, "Evaluation of selected plant extracts for in vitro anti-marine leech (Zeylanicobdella arugamensis) activity," Tropical Biomedicine, vol. 38, pp. 22-129, 2021.

[69] T. Teklehaymanot, "Ethnobotanical study of knowledge and medicinal plants use by the people in Dek Island in Ethiopia," Journal of Ethnopharmacology, vol. 124, no. 1, pp. 69-78, 2009.

[70] H. T. Bekalo, S. Demissew, and Z. Asfaw, "An ethnobotanical study of medicinal plants used by local people in the lowlands of konta special wereda, southern nations, nationalities and peoples regional state, Ethiopia," Journal of Ethnobiology and Ethnomedicine, vol. 5, pp. 3-26, 2009.

[71] N. Abdurhman, "Ethnobotanical study of medicinal plants used by local people in Ofla Wereda, Southern Zone of Tigray region, Ethiopia," MSc thesis, Addis Ababa University, Addis Ababa, Ethiopia, 2010. 